\title{
S. Sobieszczyk
}

Gdansk University of Technology, Faculty of Mechanical Engineering, Department of Mechanical Engineering and Materials Strength, 80-952 Gdańsk, Poland,

\section{SELF-ORGANIZED NANOTUBULAR OXIDE LAYERS ON Ti AND Ti ALLOYS Review Paper}

\begin{abstract}
To improve bioactivity of titanium and titanium, the implant surface modification by formation of selforganized $\mathrm{TiO}_{2}$ nanotube arrays with electrochemical techniques is presented. The influence of electrolyte composition and deposition parameters during anodization is characterized. The enhancement of phosphates deposition by titanium nanotubular structure is discussed. The calcium phosphate ceramics is shown to be uniformly deposited on anodized titanium surface of a nanotubular oxide layer.
\end{abstract}

Key words: electrochemical anodization, nanotubes, phosphate deposition, self-organization

\section{INTRODUCTION}

Titanium implants exhibit good physic-chemical stability, mechanical integrity, good biocompatibility and excellent corrosion resistance in application as a osseointegrative implant material [1]. The osseointegration of the implant is via the natural oxide $\mathrm{TiO}_{2}$ layer, but it is a long process [2]. In order to improve the bioactivity of titanium and enhance bone growth, the modification of surface layer can be applied, e.g. roughening by sand blasting [3], hydroxyapatite coating [4] or chemical methods like acid etching and alkali treatment [5]. One of the recently studied methods of surface modification is formation of self-organized $\mathrm{TiO}_{2}$ nanotube layers, which can enhance calcium phosphate formation in comparison to dense $\mathrm{TiO}_{2}$, by various techniques such as sol-gel method [6], electrophoretic deposition [7] and anodization [8]. Electrochemical method gets more attention due to its low cost and relative ease of fabrication that the other techniques [9].

Titanium and titanium alloys with anodic tubular oxide layer are very interesting materials for applying them as high performance biomedical materials, because they have excellent physical and chemical properties as well as biocompatibility [10-13]. In order to improve bioactivity and enhance bone growth, self-organized $\mathrm{TiO}_{2}$ layers with controlled structure and morphology can be used [10,14-17]. Present research findings indicate that $\mathrm{TiO}_{2}$ nanotubes could also be applied in gas sensors [18], bio-sensors $[19,20]$, photocatalysis [21,22], photoelectrolysis [20,22], photoelectronics [23] as well as successfully used for surface treatment for biocompatibility purposes [24,25]. 


\section{$\mathrm{TiO}_{2}$ NANOTUBE FORMATION}

Titanium oxide nanotubes can be prepared by various methods, like sol-gel [6], electrophoretic deposition (EPD) [7] and anodization [8]. The latest one is the best for nanotubular oxide layer creation for biological applications, as it enables to achieve the highest adhesion strength of the layer comparing to that of sol-gel and EPD.

There are some gaps between adjacent nanotubes of $\sim 15 \mathrm{~nm}$, which are important for minimizing the interfacial stresses between two dissimilar materials joined. Also, such gaps between nanotubes create pathways for body fluid supply with ions, nutrients, and proteins [14].

The typical nanotube arrays consist of single nanotubes of $80-150 \mathrm{~nm}$ in diameter and $0.5-25 \mu \mathrm{m}$ in length [26,27]. The physical and chemical properties of nanotube layer can be controlled by changing the parameters of fabrication process [8,15,26,28-31].

The $\mathrm{TiO}_{2}$ nanotube arrays formation in $\mathrm{F}^{-}$- containing electrolytes is a result of two competing electric field-assisted processes: hydrolysis of Ti metal to form $\mathrm{TiO}_{2}$ (1) and chemical dissolution of $\mathrm{TiO}_{2}$ at the oxide/electrolyte interface (2) [32,33], which is presented in Fig. 1:

$$
\begin{gathered}
\mathrm{Ti}^{4+}+2 \mathrm{H}_{2} \mathrm{O} \rightarrow \mathrm{TiO}_{2}+4 \mathrm{H}^{+} \\
\mathrm{TiO}_{2}+6 \mathrm{HF} \rightarrow\left[\mathrm{TiF}_{6}\right]^{2}+2 \mathrm{H}_{2} \mathrm{O}+2 \mathrm{H}^{+}
\end{gathered}
$$

The exact mechanism of $\mathrm{TiO}_{2}$ nanotube formation and self-ordering kinetics is the subject of very intensive research but it remains still unclear [8,27-29,31,32,34-41].

The process of $\mathrm{TiO}_{2}$ tube growth consists of three stages, as explained in detail by Crawford et al. [32]:

1. Initial barrier layer formation - there is an exponential decrease in anodic current density until it reaches the steady state. A current drop is due to the formation of compact oxide film which increases the resistance reducing the current density [42].

2. Formation of uniformly distributed pores - chemical dissolution of barrier oxide layer and increase in current density. During this stage, nanopores are formed by random local dissolution of $\mathrm{TiO}_{2}$ surface, as often indicated [36,41,43,44]. Beranek suggests that pore formation at the beginning takes place at random locations, and self-organization of pores is the effect of completion of simultaneous processes (1) and (2). Raja et al. [45] suggest that pore's ordering is the effect of local surface perturbations, where the strain energy increases causing the migration of $\mathrm{F}^{-}$ions to regions with higher strain energy and of hydrogen ions in order to maintain electrical neutrality, and leading to the dissolution of $\mathrm{Ti}^{4+}$ ions.

3. Separation of interconnected pores into nanotubes - the current density again stabilizes. The nanotubes formation is the result of simultaneous growth of voids (regions between pores which are susceptible to field-assisted oxidation/dissolution) and pores as suggested by Mor et al. [44]. In contrast, Raja et al. [45] claims that separation of pores into individual nanotubes may be a result of repulsive force between cation vacancies. After $1 \mathrm{~h}$ nanotubes are grown, as confirmed also by Crawford [32]. 
a

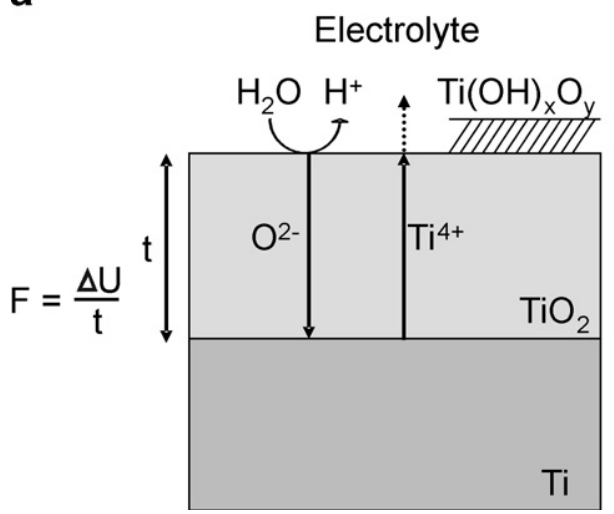

b

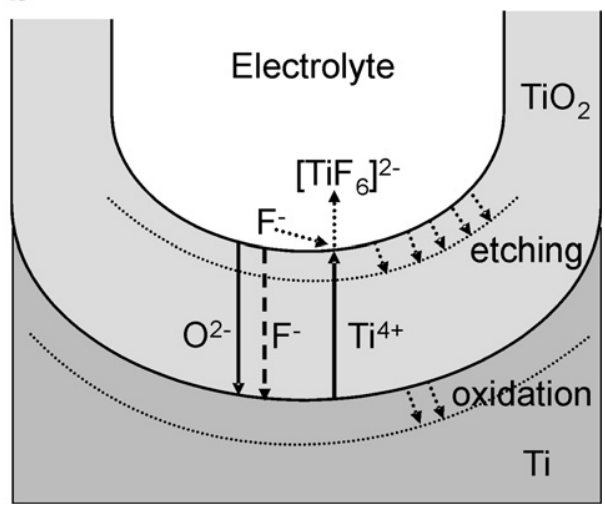

Fig. 1. Schematic representation of processes in TiO2 nanotube formation during anodization a) in absence of fluorides, and b) in presence of fluorides [36]

On the basis of the reports on growth mechanism of titania nanotube arrays, the nanotube formation can be schematically represented by Fig. 2 [46].

(a)

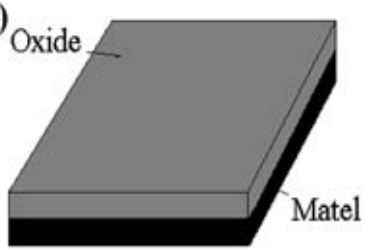

(d) (b)

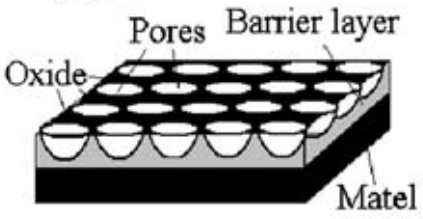

(c)

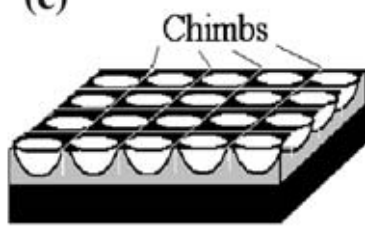

(e)

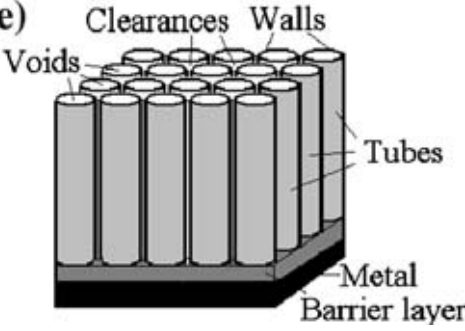

Fig. 2. Schematic diagram of the evolution of titania nanotubes in anodization: (a) oxide layer formation; (b) pore formation on the oxide layer; (c) chimbs formation between pores; (d) growth of the pores and the chimbs; (e) fully developed titania nanotube arrays [46]

\section{Effect of electrolyte}

A vertically aligned nanotube array of titanium oxide can be fabricated on the surface of titanium substrate by anodization in slightly dissolving fluoride-containing electrotyles [14,17,29,46-48]. Electrolytes without fluoride, e.g. sulfuric acid [9] have been widely used to fabricate a nonporous compact titanium oxide layer at low potential, and porous oxides at high potentials due to the electrical breakdown of the oxide [49]. Anodization in fluoride-containing electrolytes results in ordered nanotube arrays, rather than porous or nonporous structures of the oxides. Chemical composition and nanotube architecture can be adjusted by the type of electrolytes, voltages and anodic oxidation times. 
Table. 1. Aqueous electrolytes for anodic oxidation

\begin{tabular}{|c|c|c|c|c|c|c|}
\hline Electrolyte & $\begin{array}{c}\text { Voltage } \\
{[\mathrm{V}]}\end{array}$ & $\begin{array}{c}\text { Duration } \\
{[\mathrm{h}]}\end{array}$ & $\begin{array}{c}\text { Outer } \\
\text { diameter of } \\
\text { nanotube } \\
{[\mathrm{nm}]}\end{array}$ & $\begin{array}{c}\text { Nanotube } \\
\text { length } \\
\text { [nm] }\end{array}$ & $\begin{array}{c}\text { Wall thickness } \\
\text { of nanotube } \\
{[\mathrm{nm}]}\end{array}$ & Reference \\
\hline \multirow{6}{*}{0,5 wt. $\% \mathrm{HF}+\mathrm{H}_{2} \mathrm{O}$} & 20 & 0.33 & 100 & & 15 & [56] \\
\hline & 20 & 0.5 & 100 & $0.25 \div 250 \mu \mathrm{m}$ & 15 & [14] \\
\hline & 20 & 0.5 & 100 & & & [57] \\
\hline & 40 & 24 & 170 & $12 \mu \mathrm{m}$ & 30 & [17] \\
\hline & & 0.5 & 100 & 250 & 15 & [58] \\
\hline & & 0.33 & 80 & 400 & & [59] \\
\hline \multirow{4}{*}{$\begin{array}{l}1 \mathrm{~m} \mathrm{H}_{2} \mathrm{SO} 4+ \\
0.3 \div 0.5 \text { wt. } \% \mathrm{HF}\end{array}$} & 20 & 2 & 100 & 500 & 15 & [60] \\
\hline & & & & 500 & & [41] \\
\hline & 20 & 0.5 & $20 \div 30$ & 500 & & [61] \\
\hline & 12 & 4 & 40 & $0.12 \mu \mathrm{m}$ & & [55] \\
\hline \multirow{2}{*}{$\begin{array}{l}1 \mathrm{~m} \mathrm{H}_{2} \mathrm{SO}_{4}+0.1 \mathrm{~m} \\
\mathrm{NaF}\end{array}$} & 20 & $0.25 \div 4$ & $45 \div 50$ & $234 \div 625$ & $12 \div 15$ & {$[32]$} \\
\hline & 20 & 2 & $20 \div 150$ & $0.25 \div 720 \mu \mathrm{m}$ & $7 \div 35$ & [62] \\
\hline \multirow{8}{*}{$\begin{array}{l}0.5 \div 1 \mathrm{~m} \mathrm{H}_{3} \mathrm{PO}_{4}+ \\
0.3 \div 0.5 \text { wt. } \% \mathrm{HF}\end{array}$} & 20 & $0.5 \div 12$ & & $250 \mathrm{~nm} \div 1 \mu \mathrm{m}$ & & [63] \\
\hline & 20 & 2 & $60 \div 100$ & $400 \div 500$ & & {$[7]$} \\
\hline & 20 & 2 & 100 & $1 \div 2 \mu \mathrm{m}$ & & [10] \\
\hline & 10 & 2 & 50 & & & [30] \\
\hline & $1 \div 25$ & & $15 \div 120$ & $500-600$ & & [36] \\
\hline & & 2 & 110 & $1.1 \mu \mathrm{m}$ & & [64] \\
\hline & 20 & 2 & 100 & $1 \mu \mathrm{m}$ & 10 & [65] \\
\hline & 10 & 2 & & 500 & & [66] \\
\hline \multirow{2}{*}{$\begin{array}{l}0,5 \mathrm{~m} \mathrm{H}_{3} \mathrm{PO}_{4}+ \\
0.138 \mathrm{~m} \mathrm{NaF}^{+}\end{array}$} & 20 & 2 & $60 \div 100$ & $400 \div 500$ & $\sim 20$ & [7] \\
\hline & 20 & $28 \mathrm{~min}$ & 100 & & & [50] \\
\hline \multirow{2}{*}{$\begin{array}{l}1 \mathrm{~m} \mathrm{NaH}_{2} \mathrm{PO}_{4}+0.5 \\
\text { wt. } \% \mathrm{HF}\end{array}$} & 20 & 2 & & $1 \mu \mathrm{m}$ & & [66] \\
\hline & 20 & 2 & & & & [67] \\
\hline 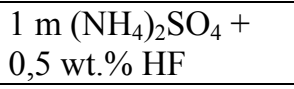 & & 2 & 100 & $2.5 \mu \mathrm{m}$ & & [68] \\
\hline \multirow{4}{*}{$\begin{array}{l}1 \div 2 \mathrm{~m}\left(\mathrm{NH}_{4}\right)_{2} \mathrm{SO}_{4} \\
+0.1 \div 0.5 \mathrm{wt} . \% \\
\mathrm{NH}_{4} \mathrm{~F}\end{array}$} & 20 & & $50 ; 100$ & & & [69] \\
\hline & & 3 & 50 & & & [52] \\
\hline & & 2 & 90 & $10.7 \mu \mathrm{m}$ & & [70] \\
\hline & 20 & 4 & $60 \div 80$ & 300 & & [71] \\
\hline $\begin{array}{l}0 \div 2 \mathrm{~m}\left(\mathrm{NH}_{4}\right)_{2} \mathrm{SO}_{4} \\
+0.5 \text { wt. } \% \mathrm{HF}\end{array}$ & & 6 & $20 \div 110$ & $110 \div 700$ & & {$[72]$} \\
\hline \multirow{2}{*}{$\begin{array}{l}1 \mathrm{~m} \mathrm{Na} \mathrm{SO}_{4}+0.5 \\
\text { wt. } \% \mathrm{NaF}\end{array}$} & 20 & 3 & 100 & $1.66 \mu \mathrm{m}$ & $10 \div 20$ & [26] \\
\hline & 20 & 2 & & & & [62] \\
\hline \multirow{2}{*}{$\begin{array}{l}1.75 \mathrm{~m} \mathrm{H}_{2} \mathrm{SO}_{4}+ \\
0.1 \div 0.5 \mathrm{~m} \mathrm{NH}_{4} \mathrm{~F}\end{array}$} & & 1 & 120 & 300 & & [46] \\
\hline & & & 120 & 300 & & [73] \\
\hline \multirow{2}{*}{$\begin{array}{l}0.3 \div 1 \mathrm{~m} \mathrm{H}_{3} \mathrm{PO}_{4}+ \\
0.135 \mathrm{~m} \mathrm{NH}_{4} \mathrm{~F}\end{array}$} & 20 & & $50 \div 100$ & & & [74] \\
\hline & & 2 & $90 \div 180$ & 400 & $10 \div 20$ & [75] \\
\hline
\end{tabular}

There are different kinds of solutions, among them are several aqueous electrolytes [9,50] which have been used to create $\mathrm{TiO}_{2}$ tubular structures. Li [17] has noticed that when using aqueous electrolytes, nanotubes are short in length and contain ridges and circumferential serrations (Table 1). The smooth, long and ridges-free nanotubes can be achieved in highly viscous organic electrolytes like glycerol and ethylene glycerol electrolytes as well as fluorinated dimethyl sulfoxide and formamide [17,27,51-54]. It has been confirmed that if the anodization treatment is carried out in less aggressive electrolytes like ethylene glycol solutions containing HF, higher thickness of layer can be achieved, up to $250 \mu \mathrm{m}[40,55]$. 
The investigations indicated that $\mathrm{pH}$ of the electrolyte influences the thickness of the nanotubular $\mathrm{TiO}_{2}$ layer [26,53]:

$\mathrm{pH}$ up to $1-$ the thickness of $\mathrm{TiO}_{2} \sim 1 \mu \mathrm{m}$

$\mathrm{pH}$ neutral - the thickness $\sim 2 \mu \mathrm{m}$ (in solution of $\left(\mathrm{NH}_{4}\right)_{2} \mathrm{SO}_{4}$

$\mathrm{pH}$ (ethylene glycol solution) - the thickness $\geq 250 \mu \mathrm{m}$

The concentration of HF has significant influence on creation of tubular structure of oxide film. In electrolytes whose acidity is too high or too low, no titania nanotube arrays can be formed. According to Schmuki [52], anodization in $0.15-0.4 \mathrm{wt} \% \mathrm{HF}$ concentration enables nanotubular formation. Concentration less than $0.15 \mathrm{wt} \%$ results in disordered and spongy-like porous titanium oxide films. Also, when increasing HF concentration (from 0.15 to $0.4 \mathrm{wt} \%$ ), the average pore diameter and pore spacing decreases, from 89 to $56 \mathrm{~nm}$ and 156 to $106 \mathrm{~nm}$, respectively [42].

The anodization process resulting in $\mathrm{TiO}_{2}$ nanotube formation in aqueous electrolytes (not only) is often performed by using a $20 \mathrm{~V}$ anodization voltage for 20-30 minutes at room temperature $[7,14,50,58]$.

\section{Effect of anodization voltage}

The structure of nanotubular $\mathrm{TiO}_{2}$ arrays depend on the voltage applied during anodic oxidation due to the equilibrium between electrochemical formation of titania and the chemical dissolution of titania in fluoride-containing electrolytes $[37,46]$. The tube diameter and thickness can be adjusted by changing the applied voltage, anodization time and $\mathrm{pH}[10,29,75]$. The investigations have indicated that tube diameters and layer thickness linearly depend on the applied potential (Table 1). This is in line with the experimental findings [75]. Kodama et al. [10] also have noticed that change in the $\mathrm{pH}$ of electrolytes affects the layer thickness while keeping the diameter constant.

It is important to note that the higher anodization potential is, the larger elements of the arrays are formed [30.46,76]. The results have been confirmed by Bestetti et al. [42] during the anodization in $1 \mathrm{M} \mathrm{H}_{2} \mathrm{SO}_{4}$ and $0.15 \mathrm{wt} . \% \mathrm{HF}$ at $10-35 \mathrm{~V}$. An increase in cell voltage from 10 to $25 \mathrm{~V}$ results in increasing average pore diameter from $30 \mathrm{~nm}$ to 150 $\mathrm{nm}$. At $30 \mathrm{~V}$ of voltage and above this value the nanotubular structure disappears.

\section{Effect of current density}

In the first few seconds of anodization process there is an exponential current density decrease due to the formation of compact oxide film, then the current density starts to grow as the solubility of the Ti oxide increases [42]. The investigations have shown that there is a characteristic peak current before it starts to decrease and stabilize $[61,77]$ which is related to transition from an initial irregular sponge-like porous structure to an ordered tubular structure. The decrease in current density is related to the diffusion distance that increases following the growth of nanotubes [70,77].

The current values during anodization process show regular periodical fluctuations due to the growth and dissolution of the oxide film, passivation and depassivation reactions related to $\mathrm{TiO}_{2}$ nanotube formation [40,42]. The experiments carried out by Macak et al. [40] revealed also that periodical of current oscillation have influenced the structural features of the nanotube causing ripples on their walls. The exact mechanism of the interaction between current oscillations and structural features is still unknown $[29,40,78]$. 
The fluctuations of the current density may be attributed to hydrogen bubbles produced during anodization which remain on cathode surface until they have sufficient buoyancy to break free from the surface, as have been indicated by experiments of Kaneco et al. [28]. In order to reduce hydrogen bubble size, methanol can be added to the solution to enhance the hydrogen removal from the cathode surface. Methanol reduces the hydrogen bubble size due to the reduction in surface tension. Methanol also enables to control the current density precisely as shown in Kaneco experiments [28].

Kaneco et al. [28] reported the results obtained during anodic oxidation in methanol and water mixture electrolytes in presence of $1 \mathrm{wt} . \% \mathrm{HF}$ under constant-current conditions, by adjusting the voltage. The results show that by controlling the current density during the electrolysis the tubes of different diameter could be produced. The current density plays a significant role in nanotube formation with respect to pore size and morphology. As the current density increases, the electrochemical etching rate, power and electric field intensity increase.

\section{Effect of anodization duration}

Crawford et al. [32] reported that the tube diameter and wall thickness do not vary significantly with anodization time. Their foundings are well in line with the observations made by other researchers under similar conditions of processing $[37,79]$.

\section{Effect of temperature}

Prida et al. [42] reported the temperature influence on the growth of self-ordered $\mathrm{TiO}_{2}$ arrays. Especially, a low temperature (about $2-3^{\circ} \mathrm{C}$ ) inhibits the nanotubular structure formation resulting in sponge-like randomly porous structure. Typically, anodic oxidation is conducted at room temperature [14,17,29,47].

\section{Wettability of $\mathrm{TiO}_{2}$ nanotubes}

The hydrophobic and hydration forces play a significant role for biological systems in protein adsorption and cell adhesion [42]. The nanotube oxide layer can alter surface properties like wettability modifying titanium surface from hydrophobic to hydrophilic because the nanotubular structure allows the liquid to penetrate deeper into the film and then decreasing a contact angle $[33,68]$. As a result, higher hydrophilicity and surface energy improve the ability to apatite forming in simulated body fluid (SBF) [33].

The wettability of the tube surface also can be adjusted by an attachment of monolayer of some compounds (octadecylsilane or octadecylphosphonic acid) on the surface by UV-light treatment. The modification of tubular $\mathrm{TiO}_{2}$ was found to be extremely stable over time in contrast to UV modified dense $\mathrm{TiO}_{2}$ surface [68].

\section{Effect of water content and viscosity}

The water content in electrolytes affects strongly the tube geometry as shown in ethylene glycol and glycerol water mixtures [30,40,52]. The tubes have significantly higher length and smooth morphology in less aggressive electrolytes, like organic nonacidic electrolytes $[55,68]$.

\section{Alkali treatment}


$\mathrm{NaOH}$ is added to the electrolyte in order to adjust the $\mathrm{pH}$ to different values enhancing the bioactivity of titanium oxide nanotubes $[10,14,56]$.

HAp formation can be accelerated by creation of sodium titanate layer when titanium surface is subjected to $\mathrm{NaOH}$ treatment followed by heat treatment [14,58]. The nanofiber structure appears at the top of nanotubes possibly due to the surface tension related to $\mathrm{NaOH}$ which has difficulty in getting into and between $\mathrm{TiO}_{2}$ nanotubes $[14,58]$. The sodium titanate composed of mixture of $\mathrm{Na}_{2} \mathrm{Ti}_{5} \mathrm{O}_{11}$ or $\mathrm{Na}_{2} \mathrm{Ti}_{6} \mathrm{O}_{13}$ about $8 \mathrm{~nm}$ in diameter and 50-100 $\mathrm{nm}$ in length [58].

The metallic titanium with titania nanotube arrays significantly shortens the time required for the alkali treatment to initiate the apatite formation after only $30 \mathrm{~min}$. For titanium without titania arrays the apatite appears after at least $24 \mathrm{~h}$ [56]. It is noteworthy to say that there is no apatite formation on titania nanotube arrays without $\mathrm{NaOH}$ treatment after soaking in 1.5 x SBF [56].

\section{Acid etching}

The etching process removes the native oxide layer and is applied in preparation process prior to anodization process $[27,50]$.

The etching process of the titanium surface leads to surface roughness, which is important for increasing wettability of HAp precursor solution on the substrate and enhancing mechanical interlocking between HAp layer and substrate $[9,14,50]$.

\section{Annealing treatment}

As-formed nanotube layer is amorphous [10]. Annealing of the amorphous nanotube layer transforming this form to anatase or a mixture of anatase and rutile can enhance the apatite formation $[10,58]$. It is well established that anatase phase is more efficient in nucleation and growth of apatite than the rutile phase of $\mathrm{TiO}_{2}$ because of the better crystal lattice match with HAp phase [58].

Heat treatment can be conducted at different temperatures $\left(300-600^{\circ} \mathrm{C}\right)$ resulting in the phase change of tubular oxide. After anodization, the $\pi-\mathrm{TiO}_{2}$ layer is amorphous as has been observed by Li et al. [17], The tests show that after heat treatment at $300^{\circ} \mathrm{C}$ there is anatase $\pi-\mathrm{TiO}_{2}$ phase while heat treatment in higher temperature of $500^{\circ} \mathrm{C}-600^{\circ} \mathrm{C}$ gives some rutile $\mathrm{TiO}_{2}$ phase (a mixture of anatase and rutile) [17]. There is a gradual transition from anatase to rutile phase when increasing a temperature. Oh et al. [58] also noticed that heat treatment $\sim 500^{\circ} \mathrm{C}$ produces anatase crystal structure of $\mathrm{TiO}_{2}$ but heating in a higher temperature, exceeding $600^{\circ} \mathrm{C}$ results in the undesirable rutile structure and even some collapse of $\mathrm{TiO}_{2}$ nanotubes. It is well in line with the observation made by Macak et al. [40].

It is noteworthy that as formed nanotubes have some components of hydroxides built-in on the surface of walls and quite significant amounts of fluoride ions are present in $\mathrm{TiO}_{2}$ structure [81]. After annealing, an almost complete loss of the fluorides is noticed at around $300^{\circ} \mathrm{C}$ and surface of hydroxides is also reduced [40].

Kunze et al. [26] have noticed that the nucleation rate of apatite is high also for nonannealed $\mathrm{TiO}_{2}$ nanotubes, but no homogeneous growth of apatite occurs due to the amorphous structure of the oxide. The crystallographic structure does not play an important role in the nucleation of apatite on tubular films at the initial stage of apatite growth, as similar content of $\mathrm{Ca}$ and $\mathrm{P}$ are measured, no matter if the nanotubes are annealed or non-annealed. However, at later growth stages, the crystallographic 
structure of the substrate is substantial for homogeneous apatite formation as only on crystalline substrate the stable growth of apatite is possible [26].

The time exposure to SBF is very important, as the amount of apatite at different time exposure remains low as a function of time for non-annealed $\mathrm{TiO}_{2}$, but the significant increase is observed for annealed $\mathrm{TiO}_{2}$ nanotubes [26].

Moreover, the investigations carried out by Kodama et al. [10] have indicated that heat treatment do not alter the tubular morphology of layers. As shown on crystalline tubes the precipitate apatite is formed from a flower-like initial layer passing then to a compact thick apatite film with the typical fiber-like structure of biomimetic apatite [43]. As a comparison, on amorphous titanium layer the initial flower-like layer does not develop further into the compact apatite film.

In case of pure nanotubular $\mathrm{TiO}_{2}$ at annealing temperature $450^{\circ} \mathrm{C}$ the amorphous phase changes to anatase form. There is a difference in case of $\mathrm{Ti}_{\mathrm{x}} \mathrm{Nb}_{\mathrm{y}} \mathrm{O}_{\mathrm{z}}$ tubes as niobium atoms are inhibiting the anatase nucleation and growth processes [47]. Self-organized amorphous $\mathrm{Ti}_{\mathrm{x}} \mathrm{Nb}_{\mathrm{y}} \mathrm{O}_{\mathrm{z}}$ tubes transform into anatase $\mathrm{TiO}_{2}$ after annealing at $550-650^{\circ} \mathrm{C}$.

\section{FABRICATION OF NANOTUBE OXIDE LAYERS ON TI ALLOYS}

The nanostructures on $\mathrm{Ti}$ alloys are different from those obtained on $\mathrm{Ti}$ substrate $[27,78,80]$ with micro and nanoscale hierarchical surface obtained [27]. Tsuchiya et al. [69] have reported self-organization of nanotube layers of two distinct sizes and arrangements on Ti-Nb-Ta-Zr. Yasuda and et al. [82] presented the self-organized zirconium titanate nanotube multilayers that were grown by a repeated anodization sequence under different conditions. The bimodal morphology of nanotubes was reported for $\mathrm{Ti} 45 \mathrm{Nb}$ [77] and Ti28Zr8Nb alloys [78], related to cooperation between the two alloying elements and their oxides. After $60 \mathrm{~min}$ of anodization in $1 \mathrm{M}\left(\mathrm{NH}_{4}\right)_{2} \mathrm{SO}_{4}$ solution with an addition of $0.25 \mathrm{M} \mathrm{HF}$ at ambient temperature, two-scale selforganization processes have been established with ordered arrangements of nanotubes of $157 \mathrm{~nm}$ and $280 \mathrm{~nm}$ in diameter. It is noteworthy that the diameters of both smaller tubes and larger nanotubes reveal a linear dependence on the applied potential when applying potential from 15 to $50 \mathrm{~V}$. After the potential reaches $55 \mathrm{~V}$ the nanotubes are loosing self-organization starting to have irregular arrangement [77].

\section{HAP DEPOSITION INTO $\mathrm{TiO}_{2}$ NANOTUBES}

The formation of bone-growth-related material such as calcium phosphate is an important issue for biomedical implants as a bone is a calcium phosphate based material containing 70\% HAp. In order to enhance the formation of such calcium phosphate, the morphology and kinetic of hydroxyapatite growth have been studied $[14,26]$.

The investigations on the preparation of HAp coating on the $\mathrm{TiO}_{2}$ nanotubes were seldom reported $[10,50,58]$. 
Kodama et al. [10] have suggested that $\mathrm{TiO}_{2}$ nanotube layer can significantly stimulate forming of apatite layers by soaking in SBF comparing with 'solid' oxide layer on titanium. Also, the $\mathrm{TiO}_{2}$ nanotubes promote the formation of very thick apatite films, whereas on solid (compact) $\mathrm{TiO}_{2}$ surfaces the apatite layer becomes much thinner [26]. Calcium phosphate can be deposited onto nanotubular $\mathrm{TiO}_{2}$ layer by electrodeposition in an electrolyte containing salts (table 3) [7,50]. The coating morphology can be controlled in the process of electrochemical deposition by varying the electrochemical potential, current density, electrolyte concentration and temperature [83].

Table 3. Electrolytes for calcium phosphate electrodeposition

\begin{tabular}{|c|c|c|c|}
\hline Electrolyte & $\begin{array}{l}\text { Temp. } \\
{\left[{ }^{\circ} \mathrm{C}\right]}\end{array}$ & $\begin{array}{c}\mathrm{pH} \\
\text { electrolite }\end{array}$ & Reference \\
\hline $\begin{array}{l}0.04 \mathrm{M} \mathrm{Ca}\left(\mathrm{NO}_{3}\right)_{2}+0.027 \mathrm{M} \\
\mathrm{NH}_{4} \mathrm{H}_{2} \mathrm{PO}_{4}+0.1 \mathrm{M} \mathrm{NaNO}_{3}\end{array}$ & 25 & 4,5 & [50] \\
\hline $\mathrm{Ca}(\mathrm{OH})_{2}+0.02 \mathrm{M}\left(\mathrm{NH}_{4}\right)_{2} \mathrm{HPO}_{4}$ & 25 & & [10] \\
\hline $\begin{array}{l}0.04 \mathrm{M} \mathrm{Ca}\left(\mathrm{NO}_{3}\right)_{2}+0.027 \mathrm{M} \\
\mathrm{NH}_{4} \mathrm{H}_{2} \mathrm{PO}_{4}+0.5 \mathrm{M} \mathrm{NaCl}\end{array}$ & 65 & 4 and 6 & [7] \\
\hline
\end{tabular}

In order to deposit $\mathrm{CaP}$ starting from the bottom of nanotubes, the potential pulsing was applied in two step process composed of first pulsing the potential between $-1200 \mathrm{mV}$ and $200 \mathrm{mV}$ for 60 cycles and then applying a constant potential of $-1200 \mathrm{mV}$ [7]. In contrast, Wang et al. [50] used cathodic deposition of calcium phosphate onto nanotubular oxide at a constant potential of $3 \mathrm{~V}$, where the HAp nanocrystals were anchored inside and between the nanotubes.

Kodama et al. [10] used alternative immersion method (AIM) treatment which preloads nanotubes with synthetic HAp, achieving flake-like deposits on the nanotube layer as well as inside each single tube. The experiments reveal that there is a linear dependence of the amount of synthetic HAp with increasing tube diameter, giving the best results for the $100 \mathrm{~nm}$ round tubes, which means that capillary forces and diffusion length are less dominant than the available area of the tube wall and the available empty tube volume. That means that the tube diameter and tube length are the most important factors. They also noticed that without AIM treatment, no significant apatite formation could be found [10]. The nanotubular surfaces may be about 46 times as large as the respective compact $\mathrm{TiO}_{2}$ surfaces [26], so that nucleation of apatite is accelerated because a larger specific surface area is available for nucleation. As a result, nanotubular surface can carry more $\mathrm{OH}^{-}$groups and leads to a very dense formation of apatite nuclei. It is well known, that $\mathrm{OH}$ groups adsorbed on the oxide layer, play an important role in nucleation process since the adsorption of $\mathrm{Ca}$ is supposed to initiate the nucleation of apatite [10].

After alkali treatment (in $\mathrm{NaOH}$ ), which generally results in amorphous sodium titanate, the formation of HAp in SBF is accelerated [58]. In presence of sodium titanate the HAp can be formed by ion exchange between $\mathrm{Na}^{+}$on the host structure and $\mathrm{Ca}^{+}$in the SBF solution [15]. 


\section{BIOACTIVITY STUDIES}

The bioactivity assessment of bone-implant interface can be evaluated by in vitro apatite deposition during exposure in SBF, with ionic concentration nearly equal to human blood plasma [26]. HAp formation in SBF is influenced by the surface roughness, electrical charge of host structure, concentration and $\mathrm{pH}$ of SBF [58]. Also, according to Webster [84], the nanostructure, as it is in case of nanotubular oxide layer, significantly improves osteoblast adhesion.

The titanium specimens with tubular oxide layer have been soaked in SBF solution $[10,17]$ for $2-14$ days under static conditions at $37^{\circ} \mathrm{C}$. After soaking for only 2 days spheroidal (typical shape of apatite crystallized from SBF) apatite has been formed, 10 $\mu \mathrm{m}$ in diameter, and after 2 weeks the layer achieved the thickness of $13 \mu \mathrm{m}$.

Kodama et al. [10] proposed an alternative immersion method in which the tubular coatings are preloaded with synthetic hydroxyapatite by cyclic exposure to saturated $\mathrm{Ca}(\mathrm{OH})_{2}$ and $0.02 \mathrm{M}\left(\mathrm{NH}_{4}\right) \mathrm{HPO}_{4}$. As observed this treatment significantly promotes natural apatite formation. Additionally, AIM treatment enhances to the greatest extent the apatite deposition for amorphous nanotubes.

In SBF, $\mathrm{OH}^{-}$groups are absorbed on oxide surface resulting in $\mathrm{Ti}-\mathrm{OH}$ and the solidliquid interface. Ti-OH groups are acidic or neutral depending on the $\mathrm{pH}$ of the surrounding solution [26]. The surface shows zero net charge at the $\mathrm{pH}=5-6$ for titanium oxide. The physiological $\mathrm{pH}=7.4$ makes the surface slightly negatively charged due to the presence of deprotonated acidic hydroxides. Such a surface attracts $\mathrm{Ca}^{+}$cations which in turn react with $\mathrm{HPO}_{4}{ }^{2-}$ or $\mathrm{H}_{2} \mathrm{PO}_{4}{ }^{-}$to form calcium phosphate $[26,56]$.

Adhesion of cells such as osteoblasts is an important prerequisite to subsequent cell functions such as synthesis of extracellular matrix proteins and formation of mineral deposits. The investigation made by Webster [84] indicates that a nanostructured ceramics significantly improves osteoblast adhesion.

The osteoblastic cells can be attached well on rough surfaces in contrast to fibroblast cells which are prone to attach on smooth surface layers (unfortunately forming the fibrous tissues at the boundary interface between implant and the growing bone, inhibiting the osteoblast adherence to the implant surface and resulting in implant loosening).

For cell adhesion studies in vitro cell culture experiments, the different cells are used, e.g. MC3T3-E1 osteoblast cells (mice cells of the type CRL-2593, sub-clone 4) [14] which are seeded onto the $\mathrm{TiO}_{2}$ layer. The experiments revealed that filopodia of propagating osteoblast cells go into the vertically aligned nanopores of the $\mathrm{TiO}_{2}$ nanotubes (giving lock-in cell configuration) [14]. The number of adhered cells on the $\mathrm{TiO}_{2}$ nanotubes increases by over $400 \%$ as compared to the Ti metal.

\section{MECHANICAL PROPERTIES}

The stability and adhesion strength properties are among the most important features of implant tissue materials. It is significant to improve adhesion between the bioactive layer and implant materials as well as between bioactive layer and bone [27]. 
Tubular oxide layer enhance adhesion (bond strength) by means of 'cup and cone' structure at the interface metal-oxide which facilitates good mechanical interlocking $[17,32]$. It is known that micrometer-sized bioactive materials like HAp on Ti substrate exhibit quite poor interfacial locking. The nano-scale $\mathrm{HAp}$ or $\mathrm{TiO}_{2}$ nanotubes form much stronger bonds and stable nanoporous layer which enhances bonding strength and reduce interfacial failure [14].

The adhesion strength between the nanotubular oxide layer and Ti substrate can be evaluated by standard methods of adhesion test for coating layer like bonding pull-of method [27,32] and scratching test [27]. According to [27], the adhesion strength for crystalline nanotubes is relatively low, about $7 \mathrm{~N}$ when comparing to that of amorphous nanotubes arrays, about $40 \mathrm{~N}$. Although the annealing process enhances transformation to favorable anatase phase, it simultaneously reduces the adhesion strength about 5 times. Nevertheless, the adhesion strength is higher for nanotube oxide layer than for solid oxide layer on titanium substrate.

Crawford et al. [32] described nanomechanical characteristics of $\mathrm{TiO}_{2}$ nanotube structures. They have indicated that the coating thickness influences the delamination which occurs during nanoindentation experiments; delamination starts on unloading for thin coatings $230-250 \mathrm{~nm}$. The results suggest that in order to improve adhesion strength, the coating thickness should be increased to at least $600-650 \mathrm{~nm}$.

Raja et al. [7] measured the bond strength of nanotubular oxide layer with nanoscale calcium phosphate crystals deposited into the $\mathrm{TiO}_{2}$ arrays as of $16-19 \mathrm{MPa}$ (ISO 137792:2008 requires for bond strength the value $15 \mathrm{MPa}[85]$ ).

\section{CONCLUSIONS}

The electrochemical anodization of titanium and titanium alloys in fluorinated electrolytes is a relatively simple method to synthesize tubular structures with well defined pore size, wall thickness and tube length. Up-to-date research results indicate that by choosing specific kind of electrolyte, controlling the applied potential, $\mathrm{pH}$ value of electrolyte, and anodization time, the geometry of nanotubes determined by their diameter, nanotube wall thickness and length can be controlled. Such nanoarchitectural oxide film has a particular advantage as a biomaterial due to the large surface area and the defined geometry, and can act as an intermediate layer for calcium phosphate deposition, thus improving the bond strength between apatite and titanium substrate, and the bioactivity of biomedical implant materials.

\section{REFERENCES}

1. Geetha M., Singh A.K., Asokamani R., Gogia A.K.: Ti based biomaterials, the ultimate choice for orthopaedic implants - A review. Progress in Materials Science 54 (2009) 397-425.

2. Ducheyne P., Qiu Q.: Bioactive ceramics: the effect of surface reactivity on bone formation and bone cell function. Biomaterials 20 (1999) 2287-2303. 
3. Hedzelek W., Sikorska B., Domka L.: Evaluation of selected mechanical and chemical methods of modifications of titanium. Physicochemical Problems of Mineral Processing 39 (2005) 149-154.

4. Variola F., Yi J-H., Richert L., Wuest J.D., Rosei F., Nanci A.: Tailoring the surface properties of Ti6Al4V by controlled chemical oxidation. Biomaterials 29 (2008) 1285-1298.

5. Jonasova L., Muller F.A., Helebrant A., Strnad J., Greil P.: Biomimetic apatite formation on chemically treated titanium. Biomaterials 25 (2004) 1187-1194.

6. Maiyalagan T., Viswanathan B., Varadaraju U.V.: Fabrication and characterization of uniform $\mathrm{TiO}_{2}$ nanotube arrays by sol-gel template method. Bull. Mater. Sci., vol.29 (7) (2006) 705-708.

7. Raja K.S., Misra M., Paramguru K.: Deposition of calcium phosphate coating on nanotubular anodized titanium. Materials Letters 59 (2005) 2137-2141.

8. Yu X., Li Y., Wlodarski W., Kandasamy S., Kalantar-Zadeh K.: Fabrication of nanostructured $\mathrm{TiO}_{2}$ by anodization: A comparision between electrotyles and substrates. Sensors and Actuators B 130 (2008) 25-31.

9. Lee J-H., Kim S-E., Kim Y-J., Chi Ch-S., Oh H-J.: Effects of microstructure of anodic titania on the formation of bioactive compounds. Materials Chemistry and Physics 98 (2006) 39-43.

10. Kodama A., Bauer S., Komatsu A., Asoh H., Ono S., Schmuki P.: Bioactivation of titanium surfaces using coatings of $\mathrm{TiO}_{2}$ nanotubes rapidly pre-loaded with synthetic hydroxyapatite. Acta Biomaterialia (2009), Article in progress.

11. Oh H-J., Lee J-H., Kim Y-J., Suh S-J., Lee J-H, Chi Ch-S.: Surface characteristics of porous anodic $\mathrm{TiO}_{2}$ layer for biomedical applications. Materials Chemistry and Physics 109 (2008) 10-14.

12. Xiao X-F., Liu R-F, Tian T.: Preparation of bioactive titania nanotube arrays in $\mathrm{HF} / \mathrm{Na}_{2} \mathrm{HPO}_{4}$ electrolyte. Journal of Alloys and Compounds 466 (2008) 356-362.

13. Krupa D., Baszkiewicz J., Sobczak J.W., Biliński A., Barcz A.: Modifying the properties of titanium surface with the aim of improving its bioactivity and corrosion resistance. Journal of Materials Processing Technology 143-144 (2003) 158-163.

14. Oh S., Jin S.: Titanium oxide nanotubes with controlled morphology for enhanced bone growth. Materials Science and Engineering C 26 (2006) 1301-1306.

15. Kim S.E., Lim J.H., Lee S. C., Nam S-C., Kang H-G., Choi J.: Anodically nanostructured titanium dioxides for implant applications. Electrochimica Acta 53 (2008) 4846-4851.

16. Zhang L., Chen Y., Rodriguez J., Fenniri H., Webster T.: Biomimetic helical rosette nanotubes and nonocrystalline hydroxyapatite coatings on titanium for improving orthopedic implants. Int. Journal of Nanomedicine 3(3) (2008) 323-333.

17. Li M., Xiao X., Liu R.: Synthesis and bioactivity of highly ordered $\mathrm{TiO}_{2}$ nanotube arrays. Applied Surface Science 255 (2008) 365-367.

18. Varhgese O.K., Gong D., Paulose M., Ong K.G., Grimes C.A.: Hydrogen sensing using titania nanotubes. Sensors and Actuators, B 93, 1-3 (2003) 338-344. 
19. Liang Ch., Li X.: Effects of structure of anodic $\mathrm{TiO}_{2}$ nanotube arrays on photocatalytic activity for the degradation of 2,3-dichlorophenol in aqueous solution. Journal of Hazardous Materials 162 (2009) 1415-1422.

20. Baram N., Starosvetsky D., Starosvetsky J., Epshtein M., Armon R., Ein-Eli Y.: Enhanced inactivation of $E$. coli bacteria using immobilized porous $\mathrm{TiO}_{2}$ photoelectrocatalysis. Electrochimica Acta 54 (2009) 3381-3386.

21. Yu H., Yu J., Cheng B., Lin J.: Synthesis, characterization and photocatalytic activity of mesoporus titania nanorod/titanate nanotube composites. Journal of Hazardous Materials 147 (2007) 581-587.

22. Vitiello R.P., Macak J.M., Ghicov A., Tsuchiya H., Dick L.F.P., Schmuki P.: NDoping of anodic $\mathrm{TiO}_{2}$ nanotubes using heat treatment in ammonia. Electrochemistry Communications 8 (2006) 544-548.

23. Tsuchiya H., Macak J.M., Ghicov A., Rader A.S., Taveira L., Schmuki P.: Characterization of electronic properties of $\mathrm{TiO}_{2}$ nanotube films. Corrosion Science 49 (2007) 203-210.

24. Fahim N.F., Morks M.F., Sekino T.: Electrochemical synthesis of silica-doped high aspect-ratio titania nanotubes as nanobioceramics for implant applications. Electrochimica Acta 54 (2009) 3255-3269.

25. Bauer S., Park J., Mark K., Schmuki P.: Improved attachment of mesenchymal stem cells on super-hydrophobic $\mathrm{TiO}_{2}$ nanotubes. Acta Biomaterialia 4 (2008) 1576-1582.

26. Kunze J., Muller L., Macak J.M., Greil P., Schmuki P., Muller F.A.: Timedependent growth of biomimetic apatite on anodic $\mathrm{TiO}_{2}$ nanotubes. Electrochimica Acta 53 (2008) 6995-7003.

27. Zhang W., Li G., Li Y., Yu Z., Xi Z.: Fabrication of $\mathrm{TiO}_{2}$ nanotube arrays on biologic titanium alloy and properties. Trans. Nonferrous Met. Soc. China 17 (2007) 692-695.

28. Kaneco S., Chen Y., Westerhoff P., Crittenden J.C.: Fabrication of uniform size titanium oxide nanotubes: Impact of current density and solution conditions. Scripta Materialia 56 (2007) 373-376.

29. Petukhov D.I., Eliseev A.A., Kolesnik I.V., Napolskii K.S., Lukashin A.V., Tretyakov Y.D., Grigoriev S.V., Grigorieva N.A., Eckerlebe H.: Formation mechanism and packing options in tubular anodic titania films. Microporous and Mesoporous Materials 114 (2008) 440-447.

30. Bauer S., Kleber S., Schmuki P.: $\mathrm{TiO}_{2}$ nanotubes: Tailoring the geometry in $\mathrm{H}_{3} \mathrm{PO}_{4} / \mathrm{HF}$ electrolytes. Electrochemistry Communications 8 (2006) 1321-1325.

31. Crawford G.A., Chawla N.: Porous hierarchical $\mathrm{TiO}_{2}$ nanostructures: Processing and microstructure relationships. Acta Materialia 57 (2009) 854-867.

32. Crawford G.A., Chawla N., Das K., Bose S., Bandyopadhyay A.: Microstructure and deformation behavior of biocompatible $\mathrm{TiO}_{2}$ nanotubes on titanium substrate. Acta Biomaterialia 3 (2007) 359-367.

33. Das K., Balla V.K., Bandyopadhyay A., Bose S.: Surface modification of laserprocessed porous titanium for load-bearing implants. Scripta Materialia 59 (2008) 
$822-825$.

34. Narayanan R., Seshadri S.K.: Point defect model and corrosion of anodic oxide coatings on Ti-6Al-4V. Corrosion Science 50 (2008) 1521-1529.

35. Wilks R.G., Santos E., Kurmaev E.Z., Yablonskikh M.V., Moewes A., Kuromoto N.K., Soares G.A.: Characterization of oxide layers formed on electrochemically treated $\mathrm{Ti}$ by using soft X-ray absorption measurements. Journal of Electron Spectroscopy and Related Phenomena 169 (2009) 46-50.

36. Macak J.M., Tsuchiya H., Ghicov A., Yasuda K., Hahn R., Bauer S., Schmuki P.: Current Opinion in Solid State and Materials Science 11 (2007) 3-18.

37. Cai Q., Yang L., Yu Y.: Investigations on the self-organized growth of $\mathrm{TiO}_{2}$ nanotube arrays by anodic oxidation. Thin Solid Films 515 (2006) 1802-1806.

38. Kuromoto N.K., Simao R.A., Soares G.A.: Titanium oxide films produced on commercially pure titanium by anodic oxidation with different voltages. Materials Characterization 58 (2007) 114-121.

39. Enyashin A.N., Ivanovskii A.L.: Theoretical study on the structure and electronic properties of $\mathrm{TiO}_{2}$ nanotubes and nanowires. Journal of Molecular Structure: THEOCHEM 766 (2006) 15-18.

40. Macak J.M., Tsuchiya H., Ghicov A., Schmuki P.: Formation and properties of anodic $\mathrm{TiO}_{2}$ nanotube layers. Electrochemical Communications 7 (2005) 11331137.

41. Bestetti M., Franz S., Cuzzolin M., Arosio P., Cavallotti P.L.: Structure of nanotubular titanium oxide templates prepared by electrochemical anodization in $\mathrm{H}_{2} \mathrm{SO}_{4} / \mathrm{HF}$ solutions. Thin Solid Films 515 (2007) 5253-5258.

42. Prida V.M., Manova E., Vega V., Hernandez-Velez M., Aranda P., Pirota K.R., Vazquez M., Ruiz-Hitzky E.: Temperature influence on the anodic growth of selfaligned titanium dioxide nanotube arrays. Journal of Magnetism and Magnetic Materials 316 (2007) 110-113.

43. Beranek R., Hildebrand H., Schmuki P.: Self-organized porous titanium oxide prepared in $\mathrm{H}_{2} \mathrm{SO}_{4} / \mathrm{HF}$ electrolytes. Electrochemical Solid State Letters 6 (2003) B12-4.

44. Mor G.K., Varghese O.K., Paulose M., Mukherjee N., Grimes C.A.: Fabrication of tapered, conical-shaped titania nanotubes. Journal of Materials Research 18 (2003) 2588-2593.

45. Raja K.S., Misra M., Paramguru K.: Formation of self-ordered nanotubular structure of anodic oxide layer on titanium. Electrochemical Acta 51 (2005) 154165.

46. Tian T., Xiao X., Liu R., She H., Hu X.: Study on titania nanotube arrays prepared by titanium anodization in $\mathrm{HN}_{4} \mathrm{~F} / \mathrm{H}_{2} \mathrm{SO}_{4}$ solution. Journal of Materials Science 42 (2007) 5539-3342.

47. Aldabergenova S.B., Ghicov A., Albu S., Macak J.M., Schmuki P.: Smooth titania nanotubes: Self-organization and stabilization of anatase phase. Journal of NonCrystalline Solids 354 (2008) 2190-2194.

48. Tao J., Zhao J., Wang X., Kang Y., Li Y.: Fabrication of titania nanotube arrays on 
curved surface. Electrochemistry Communications 10 (2008) 1161-1163.

49. Yang B., Uchida M., Kim H.M., Zhang X., Kokubo T.: Preparation of bioactive titanium metal via anodic oxidation treatment. Biomaterials 25 (2004) 1003-1010.

50. Wang Y., Tao J., Wang L., He P., Wang T.: HA coating on titanium with nanotubular anodized $\mathrm{TiO}_{2}$ intermediate layer via electrochemical deposition. Transactions of Nonferrous Metals Society of China 18 (2008) 631-635.

51. Berger S., Jakubka F., Schmuki P.: Formation of hexagonally ordered nanoporous anodic zirconia. Electrochemistry Communications 10 (2008) 1916-1919.

52. Macak J.M., Schmuki P.: Anodic growth of self-organized anodic $\mathrm{TiO}_{2}$ nanotubes in viscous electrolytes. Electrochimica Acta (2006) 1258-1264.

53. Raja K.S., Gandhi T., Misra M.: Effect of water content of ethylene glycol as electrolyte for synthesis of ordered titania nanotubes. Electrochemistry Communications 9 (2007) 1069-1076.

54. Allam N.K., Grimes C.A.: Effect of cathode material on the morphology and photoelectrochemical properties of vertically oriented $\mathrm{TiO}_{2}$ nanotube arrays. Solar Energy Materials \& Solar Cells 92 (2008) 1468-1475.

55. Vega V., Cerdeira M.A., Prida V.M., Alberts D., Bordel N., Pereiro R., Mera F., Garcia S., Hernandez-Velez M., Vazquez M.: Electrolyte influence on the anodic synthesis of $\mathrm{TiO}_{2}$ nanotube arrays. Journal of Non-Crystalline Solids 354 (2008) 5233-5235.

56. Xiao X., Tian T., Liu R., She H.: Influence of titania nanotube arrays on biomimetic deposition apatite on titanium by alkali treatment. Materials Chemistry and Physics 106 (2007) 27-32.

57. Zhao J., Wang X., Chen R., Li L.: Fabrication of titanium oxide nanotube arrays by anodic oxidation. Solid State Communications 134 (2005) 705-710.

58. Oh S-H., Finones R.R., Daraio C., Chen L-H., Jin S.: Growth of nano-scale hydroxyapatite using chemically treated titanium oxide nanotubes. Biomaterials 26 (2005) 4938-4943.

59. Popat K.C., Leoni L., Grimes C.A., Desai T.A.: Influence of engineered titania nanotubular surfaces on bone cells. Biomaterials 28 (2007) 3188-3197.

60. Macak J.M., Schmidt-Stein F., Schmuki P.: Efficient oxygen reduction on layers of ordered $\mathrm{TiO} 2$ nanotubes loaded with $\mathrm{Au}$ nanoparticles. Electrochemistry Communications 9 (2007) 1783-1787.

61. Sieber I., Hildebrand H., Friedrich A., Schmuki P.: Formation of self-organized niobium porous oxide on niobium. Electrochemistry Communications 7 (2005) 97100.

62. Crawford G.A., Chawla N.: Tailoring $\mathrm{TiO}_{2}$ nanotube growth during anodic oxidation by crystallographic orientation of Ti. Scripta Materialia 60 (2009) 874877.

63. Zhao J., Wang X., Sun T., Li L.: Crystal phase transition and properties of titanium oxide nanotube arrays prepared by anodization. Journal of Alloys and Compounds 434-435 (2007) 792-795. 
64. Yang Y., Wang X., Li L.: Synthesis and growth mechanism of graded $\mathrm{TiO}_{2}$ nanotube arrays by two-step anodization. Materials Science and Egnineering B 149 (2008) 58-62.

65. Ghicov A., Tsuchiya H., Hahn R., Macak J.M., Munoz A.G., Schmuki P.: $\mathrm{TiO}_{2}$ nanotubes: $\mathrm{H}^{+}$insertion and strong electrochromic effects. Electrochemistry Communications 8 (2006) 528-532.

66. Munoz A.G.: Semiconducting properties of self-organized $\mathrm{TiO}_{2}$ nanotubes. Electrochimica Acta 52 (2007) 4167-4176.

67. Hokkanen B., Funk S., Burghaus U., Ghicov A., Schmuki P.: Adsorption kinetics of alkanes on $\mathrm{TiO}_{2}$ nanotubes array - structure - activity relationship. Surface Science 601 (2007) 4620-4628.

68. Balaur E., Macak J.M., Taveira L., Schmuki P.: Tailoring the wettability of $\mathrm{TiO}_{2}$ nanotube layers. Electrochemistry Communications 7 (2005) 1066-1070.

69. Tsuchiya H., Macak J.M., Ghicov A., Tang Y.Ch., Fujimoto S., Niinomi M., Noda T., Schmuki P.: Nanotube oxide coating on Ti-29Nb-13Ta-4.6Zr alloy prepared by self-organizing anodization. Electrochimica Acta 52 (2006) 94-101.

70. Yasuda K., Schmuki P.: Control of morphology and composition of self-organized zirconium titanate nanotubes formed in $\left(\mathrm{HN}_{4}\right)_{2} \mathrm{SO}_{4} / \mathrm{NH}_{4} \mathrm{~F}$ electrolytes. Electrochimica Acta 52 (2007) 4053-4061.

71. Wang N., Li X., Wang Y., Hou Y., Zou X., Chen G.: Synthesis of $\mathrm{ZnO} / \mathrm{TiO}_{2}$ nanotube composite film by a two-step route. Materials Letters 62 (2008) 36913693 .

72. Ryu W.H., Park C.J., Kwon H.S.: Synthesis of highly ordered $\mathrm{TiO}_{2}$ nanotube in malonic acid solution by anodization. Journal of Nanoscience and Nanotechnology 8 (2008) 1-4.

73. Tian T., Xiao X-F., She H-D., Liu R-F.: Biomimetic growth of apatite on titania nanotube arrays fabricated by titanium anodization in $\mathrm{HN}_{4} \mathrm{~F} / \mathrm{H}_{2} \mathrm{SO}_{4}$ electrolyte. Materials Science-Poland, vol.8, no.3 (2008) 487-494.

74. Ghicov A., Tsuchiya H., Macak J.M., Schmuki P.: Titanium oxide nanotubes prepared in phosphate electrolytes. Electrochemistry Communications 7 (2005) 505-509.

75. Luo B., Yang H., Liu S., Fu W., Sun P., Yuan M., Zhang Y., Liu Z.: Fabrication and characterization of self-organized mixed oxide nanotube arrays by electrochemical anodization of Ti-6Al-4V alloy. Materials Letters 62 (2008) 45124515 .

76. Macak J.M., Hildebrand H., Marten-Jahns U., Schmuki P.: Mechanistic aspects and growth of large diameter self-organized $\mathrm{TiO}_{2}$ nanotubes. Journal of Electroanalytical Chemistry 621 (2008) 254-266.

77. Feng X., Macak J.M., Schmuki P.: Flexible self-organization of two size-scales oxide nanotubes on Ti45Nb alloy. Electrochemistry Communications 9 (2007) 2403-2407.

78. Feng X.J., Macak J.M., Albu S.P., Schmuki P.: Electrochemical formation of selforganized anodic nanotube coating on Ti-28Zr-8Nb biomedical alloy surface. Acta 
Biomaterialia 4 (2008) 318-323.

79. Cai Q., Paulose M., Varghese O.K., Grimes C.A.: The effect of electrolyte composition on the fabrication of self-organized titanium oxide nanotube arrays by anodic oxidation. Journal of Materials Research 20 (2005) 230-236.

80. Tsuchiya H., Macak J.M., Ghicov A., Taveira L., Schmuki P.: Self-organized porous $\mathrm{TiO}_{2}$ and $\mathrm{ZrO}_{2}$ produced by anodization. Corrosion Science 47 (2005) 33243335.

81. Taveira L.V., Macak J.M., Tsuchiya H., Dick L.F.P., Schmuki P.: Voltage oscillations and morphology during the galvanostatic formation of $\mathrm{TiO}_{2}$ nanotubes. Journal of Electrochemical Sciences 152 (2005) B405.

82. Yasuda K., Schmuki P.: Electrochemical formation of self-organized zirconium titanate nanotube multilayers. Electrochemistry Communications 9 (2007) 615-619.

83. Narayanan R., Seshadri S.K., Kwon T.Y., Kim K.H.: Electrochemical nano-grained calcium phosphate coatings on Ti-6Al-4V for biomaterial applications. Scripta Materialia 56 (2007) 229-232.

84. Webster T.J., Ejiofor J.U.: Increased osteoblast adhesion on nanophase metals: Ti, Ti6Al4V, and CoCrMo. Biomaterials 25 (2004) 4731-4739.

85. ISO Standard : ISO 13779:2-2008:

http://www.iso.org/iso/iso_catalogue/catalogue_tc/catalogue_detail.htm?csnumber= 43827 